\title{
GTF2H3 wt Allele
}

National Cancer Institute

\section{Source}

National Cancer Institute. GTF2H3 wt Allele. NCI Thesaurus. Code C89753.

Human GTF2H3 wild-type allele is located in the vicinity of 12 q24.31 and is approximately $27 \mathrm{~kb}$ in length. This allele, which encodes general transcription factor IIH subunit 3 protein, plays a role in both mRNA synthesis from DNA templates and nucleotide excision repair. 